\title{
Putins mål: Dominans over tidligere sovjetlande
}

Af Vibeke Sperling

Vladimir Putin har mange dagsordener. For Putin handler det om angst for oprør i Rusland, om at genetablere Rusland som supermagt og om at gøre op med Ruslands følelse af underdanighed over for Vesten. Og Putin har tid til at vente.

Det begyndte med den overraskende styrke i de ukrainske oprør mod den siddende præsident Janukovitj. Disse oprør skræmte Vladimir Putin, fordi det indebar faren for, at de store russiske, folkelige demonstrationer i 2011 og 2012 igen ville få tag i Rusland. Samme angst greb andre mere eller mindre autoritære ledere i det postsovjetiske rum, men de har ikke samme militære, politiske og økonoimiske midler til at gøre noget ved det. Kremls reaktion på den orange revolution i 2004 åbnede vejen for flere års konfliktfyldt forhold imellem de to slaviske stater. Det gjorde valget af den gamle Moskva-allierede, Viktor Janukovitj, til Ukraines præsident i 2010 en ende på, indtil han begyndte at flirte med EU. Denne tilnærmelse bremsede Putin med løfter om et lån på 15 milliarder dol- lar. Men så kom opstanden for en sikker ukrainsk kurs mod vest. Et vestligt orienteret Ukraine ville true Putins vigtigste projekt i det postsovjetiske rum, en Eurasisk Union, som Ukraine var en uundværlig brik i. Uden oprøret i Ukraine havde Putin ikke taget Krim. Det står formentlig til troende, som den russiske præsident selv sagde, at han ikke engang selv vidste, at det ville ende med det - i hvert fald ikke som led i en nøje planlagt langstrakt plan.

I slutningen af april 2014 godkendte Putin en lovændring, der gjorde det meget lettere for russisk-talende at få russisk statsborgerskab. Lagde han dermed an til mulig militær indgriben i stil med Krim i hele det postsovjetiske område efter devisen om, at Rusland forbeholder sig ret til at gribe ind for at beskytte russisk-talende overalt? Verden svæver i vildrede om, hvad Putins endemål er. En del af forklaringen er, at Putin måske ikke selv ved det. Det ser undertiden ud, som om hans ene hånd ikke ved, hvad den anden gør. Vil han annektere andre dele af Ukraine? Eller vil han splitte det op, så det sydøstlige Ukraine bliver en russisk satellitstat. Ifølge $\mathrm{Pu}$ tins egne udtalelser tilstræber han et Novo-

Vibeke Sperlin er journalist og Østeuropakorrespondent ved dagbladet Politiken og tidligere redaktør af Udenrigs. 
rossija, Nyt Rusland, et tsaristisk navn, som han genintroducerede 17. april, selvsamme dag, hvor Rusland, USA, Ukraine og EU underskrev en forsoningsaftale i Geneve.

"Alle disse områder blev overdraget til Ukraine i 1920'erne af den sovjetiske regering. Guderne må vide, hvorfor den gjorde det", sagde Putin.

Andrej Illarionov, der er tidligere økonomisk chefrådgiver for Putin, tolker præsidentens udtalelser på følgende måde: "Putins mål er nu Novorossija. Det er denne russers historiske mission".

Peter Zalmayev, direktør for Euroasian Democracy Initiative (EDI), skrev i en artikel bragt af bl.a. Al Jazeera: "Med alle de forudgående begivenheder i Moldovas løsrivelsesregion Transdnjestr og Georgiens Abkhasien og Sydossetien, som altsammen er under russisk kontrol, er Ukraine den vigtigste del af Moskvas fremvoksende politik for Nyt Rusland, som Putin har formuleret det".

Selv om Novorossija i første omgang gjaldt Ukraines sydøstlige provinser, som Putin ser som historisk russisk territorium, er denne politik en del af det store erklærede mål om at forsvare russisktalende overalt, om de så er i fare eller ej. "Denne nye doktrin har implikationer langt uden for Ukraines grænser og kan omfatte alle områder i det tidligere USSR med store russiske mindretal", mener Peter Zalmayev.

Putin har øjensynlig tid til at vente. Som en dreven taktiker ved Putin, at hvis han presser alt for hårdt på, kan det skade Rusland. Vestlige trusler om hårde sanktioner og EU's strategi for at lette afhængigheden af russisk gas viser dette. Med fire år til næste russiske præsidentvalg og en stor chance for at vinde seks år mere kan Putin tage sin tid. Det giver ham en fordel frem for vestlige ledere, hvis politik og handlinger er underlagt langt mere kortsigtede vilkår. "Det vigtigste er nu at holde krudtet tørt og være forberedt på, at Ukraine-krisen kan vare meget længe", mener Fjodor Lukjanov, redaktør af magasinet Russia in Global Affairs, som har Ruslands udenrigsminister i ledelsen.

Det vakte et vist håb, da Rusland, USA, Ukraine og EU i påsken indgik aftalen i Geneve, som forpligtede væbnede grupper til at nedlægge våbnene og stoppe de besættelser, der plagede det sydøstlige Ukraine. Men det omfattede også besættelsen af Uafhængighedspladsen i Kijev. Rusland tilsluttede sig i praksis hurtigt de vedholdende sydøstlige besætteres fortolkning, at den ekstremistiske ukrainske Højre Sektor og den "illegale" regering i Kijev måtte ud først. Ruslands udenrigsminister, Sergej Lavrov, var i det forsonende humør i Geneve. Putin var i krigshumør med talen om Novorossija, Nyt Rusland. De historiske bånd til Rusland kunne legitimere militær indgriben i det sydøstlige Ukraine, som annekteringen af Krim viste. Var det et 'good cop, bad cop' spil mellem Lavrov og Putin eller bare blålys, da Rusland skrev under i Geneve? Dette står ikke helt klart, men den udviste kompromisvilje afslørede sig som taktisk meningsfuld for Rusland. Og meget hurtigt brugte Moskva det som en anledning til at anklage ukrainerne for at krænke en international aftale.

\section{Propagandaspillet}

Påskemorgen angreb bevæbnede mænd de prorussiske besættere i Slavjansk. Moskva anklagede straks Højre Sektor for angrebet. Det skete med tv-billeder af et visitkort, angiveligt tilhørende lederen af Højre Sektor. Visitkortet var det enesteubeskadigede i en totalt udbrændt bil. Det samme var en nummerplade, som skulle vise, at en udbrændt bil tilhørte "ekstremister fra Kijev". Og, som Ukrainskaja Pravda fremhævede, var det højst mærkværdigt, at russisk tv var på pletten umiddelbart efter et angiveligt bagholdsangreb. Russisk propaganda kørte videre i rillen om et "fascistisk kup" i Kijev, der angiveligt truede russisk-talende på livet. Over- 


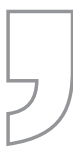

Hvis man ser på Putins propaganda i sovjetiske termer, bliver invasionen på Krim ikke et svar på reelle trusler, men snarere forsøg på at skabe trusler for at konstruere en ny virkelighed. gangsregeringen, som kom til magten i Kijev efter Viktor Janukovitjs fald, blev af Moskva og russiske medier modtaget som en bande fascister og antisemitter, selv om den var domineret af liberale konservative og en jødisk viceregeringschef. Selv om man kan diskutere de forfatningsmæssige nuancer, var der afgjort ikke tale om et kup. At reducere præsidentens magt, udskrive valg og genetablere demokratiske principper kan næppe kaldes fascisme. Det var imidlertid en stor fejltagelse, at repræsentanter for landets sydøstlige dele ikke kom med i overgangsregeringen. Det skabte forståelig folkelig vrede og gav Putin en kærkommen anledning til åben russisk indblanding. Moskvas påstand om undertrykkelse af russere i Ukraine er aldrig blevet bekræftet fra uvildigt hold, men Kijev har i lang tid overset prorusserne i det sydøstlige Ukraine.

Mange russisktalende ukrainere og medlemmer af den russiske etniske minoritet i det sydøstlige Ukraine har afvist at have behov for russisk beskyttelse. En appel til Putin om at lade ukrainere løse egne problemer blev underskevet af 140.000 mennesker i det østlige Ukraine. Men hvorfor er propagandaen så vigtig for Putins Rusland? I Sovjettiden var propagandaen ikke en redigeret version af virkeligheden, men forsøg på at skabe en ny virkelighed, som påpeget $\mathrm{i}$ en analyse på netsiden OpenDemocracy: "Propagandaen var ikke en version af den aktuelle verden, men af fremtidens. Hvis den aktuelle russiske propaganda ses i det lys, bliver det mere forståeligt, hvorfor propagandaapparatet ikke bekymrer sig så meget om faktuelle fejl og modsætninger i propagandaen. For det handler igen om at skabe en ny virkelighed".

Hvis man ser på Putins propaganda $\mathrm{i}$ sovjetiske termer, bliver invasionen på Krim ikke et svar på reelle trusler, men snarere forsøg på at skabe trusler for at konstruere en ny virkelighed. Og den russiske propaganda har været effektiv. Hvor mange overskrifter var der ikke i internationale medier, længe før det havde nogen sandhedsværdi, om faren for borgerkrig? Den fare blev introduceret af Moskva, allerede da der kun var små grupper af prorussiske demonstranter. Men fra kun at have kæppe og andre primitive våben fik de avancerede våben og andet udstyr.

\section{Fravær af rationalitet}

En tid afviste de fleste kommentatorer, at Putin kunne tænkes at invadere Ukraines sydøstlige provinser. Den uafhængige russiske militæranalytiker, Aleksandr Golts, sagde lige efter annekteringen af Krim i marts, at Rusland ikke ville rulle videre til andre dele af Ukraine, alene fordi "det ville være en langt, langt større opgave end Krim". Det ville ifølge Golts kræve omkring 100.000 mand, altså næsten alle kampklare russiske styrker.

I slutningen af april var Aleksandr Golts ikke så sikker, men skrev i Moscow Times, at den "formentlig fejlagtige opfattelse", at Putin ville standse ved Krim, deltes af mange: "Ikke fordi analytikerne var for inkompetente, men fordi de baserede deres analyser af Putin på rationelle overvejelser. Men problemet er, at rationelle argumenter synes at have ringe plads i dagens Rusland".

Analytikeren Bayram Balci skrev på tænketanken Carnegie Moskvas hjemmeside, 
at Putin modsagde sine egne visioner med Krim. Det styrkede hans prestige hjemme, "men svækkede Ruslands position i resten af det tidligere sovjetimperium, hvor Rusland mere end nogensinde ses som aggressor og utroværdig allieret".

Selv om postsovjetiske ledere i Kaukasus og Centralasien forholdt sig ret tavse om Ukraine, var de skrækslagne af to grunde. For det første, fordi de (som også Putin) frygtede samme skæbne som Ukraines Janukovitj. For det andet, fordi Ruslands militære fremfærd på Krim, viste dem, at Rusland stadig er i stand til militær indgriben i det, som det opfatter som sin indflydelsessfære. Ikke mindst Kasakhstan frygter et Krim-scenarium på sit territorium med over 25 procent russere og en meget lang grænse til Rusland ved de overvejende russisk befolkede nordlige provinser. Russiske nationalister taler nu om, at Kasakhstans nordlige provinser bør "vende tilbage til Rusland". Som på Krim har Rusland militære anlæg i Kasakhstan med Baïkanour rumcentret. Rusland har også militærbaser i Armenien, Kirgisistan og Tadsjikistan, som der på længere sigt er frygt for vil blive brugt i Putins projekt, som Sevastopol-basen blev det på Krim.

Det er tænkeligt, at Krim-annekteringen vil blive et vendepunkt for Ruslands relationer til dets postsovjetiske allierede. Det mest foruroligende for Putin er nok, at annekteringen af Krim undergraver hans drøm om en Eurasisk Union. Putin rykkede i 2000 ind i Kreml med ambitioner om at gøre en ende på Ruslands internationale ydmygelse i 1990'erne, genopbygge økonomien samt genrejse Rusland som supermagt. I den sammenhæng så han Sovjetunionens sammenbrud som århundredets "større geopolitiske katastrofe", som han sagde.

I 2011 fremlagde Putin projektet for at omdanne Ruslands eksisterende toldunion med Hviderusland og Kasakhstan til den Eurasiske Union, der skulle omfatte så mange tidligere Sovjetrepublikker som muligt. Den skulle få regionens økonomier til at blomstre ved at kombinere deres individuelle styrker og indtræde i den globale økonomi som en stærk økonomisk enhed. Putin erklærede, at unionen skulle baseres på en ny realitet, og at den intet havde at gøre med "at bringe Sovjetunionen tilbage". Dens klare omdrejningspunkt skulle dog være Rusland. Nøglen til succes for denne union har for Putin altid været Ukraine. Det er hovedårsagen til Putins vrede over revolutionen imod Janukovitj. Ifølge Vladimir Putins logik vil et totalt tab af Ukraine betyde, at den Eurasiske Union ikke bliver slagkraftig nok til at blive anset for et globalt, for ikke at tale om regionalt, magtcentrum. Efter planen skal unionen søsættes ved årsskiftet til 2014-2015.

Efter annekteringen af Krim forekommer det utænkeligt at tro, at Ukraine frivilligt kan bringes til at støtte Putins union. Mindre lande som Armenien, Tadsjikistan og Kirgisistan kan ikke kompensere for tabet af Ukraine, og de stærkeste kort i den eksisterende toldunion, Kasakhstan og Hviderusland er begyndt at vakle efter Krim-eventyret. "Putin gik for langt med interventionen på Krim. Hans spil ligner nu mere russisk roulette end en strategisk gennemtænkt politik og kan betyde hans endegyldige tab af allierede i Centralasien og Kaukasus", mener Bayram Balci.

\section{Fravær af stat}

På en pressekonference 4. marts erklærede Putin, at den ukrainske stat ikke længere eksisterede "som sådan". En retsløs zone kan der gøres, hvad som helst ved, og ifølge Putins logik uden at krænke folkeretten. Da Ruslands overhus, Føderationsrådet, autoriserede Putin til at bruge militærmagt ikke bare på Krim, men i hele Ukraine, definerede det endemålet som at genetablere "social og politisk normalitet." Hvor længe vil det mon vare, før Moskva anser Ukraine for "normaliseret"?

Putins popularitet nåede sit højeste, om- 
kring 80 procent, efter annekteringen af Krim, men det er tvivlsomt, om det bliver ved, når den begyndende recession tager til og rammer almindelige russere. Forudsigelser fra økonomiministeriet i Moskva pegede i april på en negativ vækst på 1,9 procent i 2014. Ifølge officielle russiske statistikker er kapitalflugten siden årets start kommet op på 70 milliarder dollar. Det er allerede mere end i hele 2013. Nogle internationale virksomheder ser stadig Rusland som det store investeringsmål, især i energisektoren, men Putins trussel om at beslaglægge vestlige værdier som modsvar til alvorlige vestlige sanktioner skræmte mange potentielle investorer væk.

Problemerne for russisk økonomi er meget ældre end Ukaine-krisen. Det er, som mange økonomer har påpeget, kulminationen på alvorlige strukturelle problemer, som er blevet ignoreret i perioden, hvor olie- og gaspenge fyldte statskassen. Problemerne i en økonomi, som er alt for afhængig af energiindtægter, er blevet forværret af opbygningen af en mere og mere autoritær stat.

Korruptionen sluger omkring en tredjedel af Ruslands BNP. Det svækker indenlandske entreprenørers investeringslyst, når anklagere og dommere kan benytte deres magt til at konfiskere ejendom og kapital. Små og mellemstore virksomheder bidrager kun til det russiske BNP med 24 procent. Samme tal er 58 procent i EU. Selv om vinter-OL i Sotji skulle vise det bedste af Putins Rusland, vil den langsigtede effekt nok mere blive det forhold, at et projekt budgetteret til 12 milliarder dollar endte med at koste omkring 50 milliarder dollar.

Økonomisk pres kan vise sig, som det eneste Vladimir Putin har respekt for. Kenneth Rogoff, verdenskendt økonomiprofessor ved Harvard, beskriver Putins situation ud fra sin erfaringer som stormester i skak: "Putins stilling er svag, fordi Ruslands økonomi er svag". Ifølge Rogoff er Rusland for afhængig af energieksport. Disse indtægter kan ikke sikre en anstændig levestandard for flertallet af befolkningen. Dertil kommer den grelle korruption.

\section{Putin og Nato}

Præsident Putin har taget let på Vestens relativt hårde reaktioner - også på Nato's beslutning om at nedfryse militært og civilt samarbejde med Rusland som straf for annekteringen af Krim. Det blev mødt med en afdæmpet reaktion fra Kreml, som militæreksperten Viktor Litovkin sagde til nyhedsbureauet Itar-Tass. "Vi vil fortsat hjælpe Nato-lande i anti-terroroperationer i Afghanistan og selvom samarbejdet mellem Moskva og Bruxelles aldrig har været tæt og sidstnævnte blot er kommet med erklæringer frem for handling, vil Rusland ikke kappe de militære bånd til enkelte Nato-medlemmer".

Han fremhævede samarbejdsprojekter med Frankrig, Italien og Tyskland. "Trods visse tilbageslag tror jeg, at den slags samarbejde fortsætter, fordi de er til gensidig fordel", sagde eksperten og har hidtil fået ret. "Rusland skruede ned for relationerne til Nato, efter, at alliancen havde bombet Jugoslavien i 1999. Nato suspenderede samarbejdet med Rusland efter august 2008, da Moskva slog Georgiens aggression imod Sydossetien tilbage. Der gik nogen tid, og så var tingene tilbage i den vante gang", udtalte Litovkin.

Nato har oprustet sit militære engagement i de baltiske lande og Polen, der følte sig truede af Ruslands annektering af Krim. Men netop fordi de er medlemmer af Nato og EU, er de ikke i fare for russiske angreb. Angsten i lande som Moldova og Georgien har en del større bund i virkeligheden. For Georgien har Ruslands annektering af Krim ikke ændret noget. Ruslands annektering af Sydossetien og Abkhasien efter invasionen i Georgien i august 2008 gav Rusland de facto vetoret imod georgisk Nato-medlemskab. Nato protesterede imod invasionen, men siden er episo- 
den næsten glemt. Med krav om ukrainsk neutralitet vil Putins Rusland også tiltage sig vetoret imod ukrainsk Nato-medlemskab. Moldova trues nu af krav fra løsrivelsesregionen Transdnjestr om indlemmelse i Rusland. Det er alt sammen noget, som ikke bremses af øget Nato-overvågning.

\section{Ukraine som satellitstat}

Lilja Sjevtsova, forsker ved tænketanken Carnegie i Moskva og forfatter til flere bøger om Putin, siger, at russiske tropper længe har været i Ukraine med "en specialstyrke til støtte for russere i udlandet, som blev skabt i april 2013. På Krim var det soldater fra Ruslands stedlige base, der blev brugt. Ukraine er første eksempel på, at specialstyrken er i aktion".

Men hvad mener Sjevtsova, at Putin i sidste instans vil med Ukraine? "Hans primære mål er destabilisering af landet; gøre det til en fejlslagen stat; en grå zone under Ruslands kontrol. Han ønsker det ikke som del af Rusland. Hvorfor skulle han ønske denne alt for store mundfuld? Putin vil holde Ukraine i afhængighed som en satellitstat. Og Putin vil simpelthen vise, at Vesten er for svagt til at stille noget op".

Kenneth Rogoff beskriver Putins situation ud fra sine erfaringer som stormester i skak: "Jeg tror, at hans slutspil handler om stolthed og om at give Rusland storhed tilbage. Jeg forstår, at han har portrætter af Peter den Store og Katherina den Store i sit kontor".

Annekteringen af Krim og presset på Ukraine er allerede blevet en dyr affære for Putins Rusland. Økonomisk pres er formentlig det eneste, som udefra kan påvirke Putin. Hans regime kan bringes i fare, hvis utilfredsheden breder sig i befolkningen. Om protester i befolkningen bliver en alvorlig trussel for Putin afhænger af, hvor alvorlige sanktioner Vesten påtvinger Rusland.

Der bliver ikke tale om militær konfrontation med Vesten, men økonomisk krig i det omfang, der kan skabes enighed om seriøse økonomiske sanktioner. Putin satser på fortsat at kunne spille EU-landene ud imod hinanden, som han dygtigt har gjort hidtil, når det gælder kontrakter på russisk olie og gas.

Putins situation er dobbeltsidet. På denne side er Putin svag, fordi Ruslands økonomi er svag. På den anden side er Putin stærk, fordi hans opbakning hjemme aldrig har været større. Den 'økonomiske krig' vil afgøre, om det varer ved. 